\title{
Yabancı dil olarak Türkçe öğrenen öğrencilerin ders kitapları hakkındaki görüş ve önerileri (İstanbul Türkçe Öğrenim Seti)'
}

Ahmet Zeki GÜVEN'

Uğur ÖZBILLEN²

\begin{abstract}
APA: Güven, A. Z.; Özbilen, U. (2020). Yabancı dil olarak Türkçe öğrenen öğrencilerin ders kitapları hakkındaki görüş ve önerileri (İstanbul Türkçe Öğrenim Seti). RumeliDE Dil ve Edebiyat Araştırmaları Dergisi, (Ö7), 80-91. DOI: 10.29000/rumelide.808242.
\end{abstract}

\section{$\ddot{\mathbf{O} z}$}

Türkçenin yabancı dil olarak öğretimi yaklaşık son elli yıllık süreçte gerek Türkiye'nin tarihi, kültürel ve jeopolitik konumu gerekse dünya genelinde yaşanan teknolojik gelişmeler sebebiyle büyük bir hız kazanmıştır. Bu alan öğretim programı, araç-gereç, öğretim elemanı/eğitici, yönetici ve öğretim ortamı olmak üzere birçok boyuttan oluşmaktadır. Sayılan boyutların hepsi Türkçenin yabancı dil olarak öğretimi için önem arz etmektedir. Çalışmada Türkçenin yabancı dil olarak öğretiminde kullanılan ders kitapları ele alınmıştır. Buradan hareketle araştırmada, bu alanda yaygın şekilde kullanılan kitap setlerinden biri olan “İstanbul Türkçe Öğrenim Seti” ile Türkçe öğrenen öğrencilerin set hakkındaki görüş ve önerilerini almak amaçlanmıştır. Araştırmada eylem araştırması deseni kullanılmış olup veriler görüşme tekniği ile elde edilmiştir. Veriler, öğrencilere sorulan soru ve cevapların ses kayıt cihazına kaydedilmesiyle toplanmıştır. Daha sonra kayıtlar yazıya geçirilmiştir. Çalışma grubunda toplamda 20 öğrenci yer almıştır. Çalışma grubunda yer alan 20 öğrenciye dört adet görüşme sorusu yöneltilmiş, bu sorulara verilen cevaplar kategorileştirilerek yorumlanmıştır. Araştırmanın güvenirliğini sağlamak amacıyla da veriler iki araştırmacı tarafından ayrı ayrı değerlendirilmiştir. Elde edilen veriler Miles ve Huberman (1994) tarafından önerilen formülle karşılaştırılmış ve uyumluluğun da \%96 oranında olduğu tespit edilmiştir. Araştırma sonucunda ders kitabına yardımcı nitelikte olan ses CD’lerinin ve dil bilgisi alıştırma, örnek ve konularının öğrenciler tarafından yetersiz olduğu düşünülmüş olup bu konular ile ilgili değişiklikler yapılabileceği sonucuna ulaşılabilir.

Anahtar kelimeler: Türkçenin yabancı dil olarak öğretimi, ders kitapları, öğrenci görüşleri

\section{Opinions and suggestions of the students learning turkish as a foreign language about the textbooks (Istanbul Turkish Learning Set) ${ }^{1}$}

\begin{abstract}
Teaching Turkish as a foreign language has gained a great speed thanks to both historical, cultural and geopolitical position of Turkey and technological developments worldwide for the last fifty years. This area consists of many dimensions such as curriculum, equipment, instructor / trainer, administrator and teaching environment. All of the dimensions mentioned are crucial for teaching Turkish as a foreign language. Textbooks used in teaching Turkish as a foreign language were discussed in the study. Thus, the purpose of the study is to get the opinions and suggestions of

1 Doç. Dr., Akdeniz Üniversitesi, Eğitim Fakültesi, Türkçe ve Sosyal Bilimler Eğitimi Bölümü, Türkçe Eğitimi ABD (Antalya, Türkiye), ahmetzekiguven@hotmail.com, ORCID ID: oooo-0oo2-4922-7535 [Makale kayit tarihi: 10.08.2020-kabul tarihi: 20.10.2020; DOI: 10.29000/rumelide.808242]

2 Doktora öğrencisi, Akdeniz Üniversitesi, Eğitim Bilimleri Enstitüsü (Antalya, Türkiye), ozbilenugur@gmail.com, ORCID ID: 0000-0003-4921-2568
\end{abstract}




\begin{abstract}
students learning Turkish about the set with the "Istanbul Turkish Learning Set", which is one of the widely used book sets in this field. Action research design was used in the study and the data were obtained by interview technique. The data were collected by recording the questions and answers asked to the students on a tape recorder. Then the records were written. A total of 20 students took part in the study group. Four interview questions were asked to 20 students in the study group, and the answers to these questions were categorized and interpreted. The data were evaluated by two researchers separately in order to ensure the reliability of the research. The data obtained were compared with the formula suggested by Miles and Huberman (1994) and it was found that the compatibility was $96 \%$. As a result of the research, it can be concluded that audio CDs, grammar exercises, examples and subjects which are supplementary to the textbook are found insufficient by the students and changes can be made on these issues accordingly.
\end{abstract}

Keywords: Teaching Turkish as a foreign language, textbooks, student opinions

\title{
Giriş
}

Türkçenin yabancı dil olarak öğretiminin tarihî serüveni Kaşgarlı Mahmut tarafından 1072-1074 yılları arasında Araplara Türkçeyi öğretmek amacıyla yazılan Divân-ı Lugâtü’t-Türk adlı eserle başlamaktadır (Güzel ve Barın, 2013). Divân-ı Lugâtü’t-Türk’ten sonra yabancı dil olarak Türkçe öğretimi Çağatay, Kıpçak, Osmanlı dönemlerinde Türk diline ait sözlükler ve Türkçenin öğretimine dair eserlerle devam etmiştir. Özellikle son 50 ylllık süreçte kurumsal anlamda nitelikli çalışmalar da dikkati çekmektedir. Bu konuda ilk profesyonel çalışmalar Ankara Üniversitesinde 1984 yllında Türkçe Öğretim Merkezi (TÖMER)'nin kurulması ile başlamıştır (Sarıçoban, 2015). Bu süreç 2001 yllında Diller İçin Avrupa Ortak Öneriler Çerçevesi (Common European Framework of Reference for Language, CEFR)'nin oluşturulması ile pekiştirilmiştir. Arslan ve Coşkun (2012), Diller İçin Avrupa Ortak Öneriler Çerçevesi (DİAOÖÇ)'nin oluşturulma sebebini şu şekilde açıklamışlardır: “Avrupa ülkelerinde yaşayan bireylerin birden fazla yabancı dil öğrenmelerini teşvik etmek ve de kıta Avrupa'sında çok dilliliğin ve çok kültürlülüğün devamlılı̆̆ını sağlamak için gereken ihtiyacı karşılayacağı düşünülerek hazırlanıp hayata geçirilmiştir.”. Bu noktada DİAOÖÇ Türkçenin de yabancı bir dil olarak öğrenilmesini desteklemiştir.

Günümüzde ulaşım ve teknolojik imkânların gelişerek hız kazanmasıyla birlikte yabancı dil olarak Türkçe öğretimi de hız kazanan bir eğitim alanı olmuştur. Bu alanda yakalanan ivme ile birlikte alanda kullanılan eğitim materyalleri de önem kazanmaya başlamıştır. Eğitim materyalleri öğretim sürecini, öğretim kalitesini, öğrenciyi ve öğretmeni doğrudan etkileyen en önemli unsurlardır (Hirschfelder, 1999). Ders kitaplarının öğrenciye evde de çalışma ortamı sunması, sınıf ortamında yapllacak ortak çalışmaların yürütülmesini hızlandırması, öğretmene kolaylık sağlaması, devlet desteği ile birlikte kolay ulaşılabilir olması ve bireysel öğretimi desteklemesi sayesinde de eğitim materyalleri arasında önemli bir yere sahiptir. Ayrıca ders kitaplarının kalitesi de eğitim sürecini doğrudan etkileyen önemli bir husustur. Ders kitapları biçim ve içerik özellikleriyle öğrencilerin ilgisini çekmesi, bilgiye ulaşmalarına ortam hazırlamada öğrenciyi hedeflenen kazanımlara ulaştırması açısından da önemli işlevlere sahiptir (Göçer, 2007).

Türkçenin yabancı dil olarak öğretimi ders kitaplarına gelindiğinde birçok eğitim ortamında olduğu gibi en çok kullanılan materyaller ders kitaplarıdır (Bayraktar, 2018). Daha önce de belirtildiği gibi yabancı dil olarak Türkçe öğretimi kitaplarının da çeşitli işlevleri vardır. Bu işlevler iç ve dış olarak ikiye ayrılmaktadır: İç işlev, dört dil becerisini geliştirmeye yönelik etkinliklerle öğretim sürecini kolaylaştırarak, tematik bir yaklaşımla, kültürel içeriklerle dil yapılarının harmanlanması sonucunda 
hazırlanan ünitelerin kendi içlerinde ve birbirleriyle tutarlı olmaları gerektiğini ortaya koyar. Dış işlev ise dil bilgisi konularının taksonomik olarak sıralanması, müfredatta işlenecek konuların ünitelere, ünitelerin alt ünite ve başlıklara bölünmesi, bölünen bu kısımların birbiri ile tutarlı olması, üniteler arası geçişin ölçme seviyesine uygun olması gibi kriterleri ortaya koyar (Puren, 2011'den akt. Coşkun, 2017). Ayrıca yabancı dil öğretiminde kullanılan ders kitapları, bir öğretmen, bir rehber, bir kaynak, bir eğitmen, bir otorite olabilir (Cortazzi ve Jin, 1999'dan akt. İşcan ve Yassitaş, 2018). Bu işlevler doğrultusunda ders kitaplarının kullanışlılığı ve öğretime sağladığı katkı göz ardı edilmemelidir.

Türkçenin yabancı dil olarak öğretiminde en çok kullanılan materyalin ders kitabı olması sebebiyle öğretime olan katkısının artırılması ve bu materyallerin geliştirilmesi son derece önemlidir. Bu sebeple gerek kitapların oluşturulma süreci olsun gerek yazıldıklarından sonraki süreç olsun birçok çalışma yapılmıştır. Bu çalışmalar, ağırlıklı olarak Türkçe öğretim merkezlerinde görev yapan okutman/öğretim görevlisi/usta öğreticilerle veya bu alandaki görevli akademisyenler ve uzmanlara başvurularak yapılmıştır. Çalışmalara bakıldığında; Gün, Akkaya ve Kara (2014) Türkçe öğretim merkezlerinde görev alan öğretim elemanlarıyla bir çalışma yürütmüşlerdir. Yine Kılıç ve Yenen (2015) de Türkçe öğretim merkezinde görev alan öğretim elemanlarının görüşlerine başvurmuşlardır. Karababa ve Üstünsoy Taşkın (2012)'ın çalışmalarında da diğer iki çalışmada olduğu gibi öğreten görüşlerine başvurulduğu görülmektedir. Görüldüğü gibi yabancı dil olarak Türkçe öğretimi ders kitapları hakkında görüsslerin araştırıldığı çalışmaların çoğunluğu öğretici bağlamında ele alınmıştır. Ancak alana bakıldığında öğrenen perspektifinden bu konuyu ele alan araştırma yok denecek kadar azdır. Ders kitaplarının öğreten kadar öğrenen tarafından da kullanıldığı fikrinden hareketle bu çalışmada yabancı dil olarak Türkçe öğrenen öğrencilerin ders kitapları hakkındaki görüşleri araştırılmak istenmiştir. Bu istem doğrultusunda bu alanda sıklıkla ders kitabı olarak kullanılan "İstanbul Yabancılar İçin Türkçe" (Yeşilyurt, 2019) kitapları hakkında öğrenci görüşlerine başvurulmuştur. Araştırmanın Türkçenin yabancı dil olarak öğretimi alanında yapılan diğer araştırmaların aksine konuyu farklı bir açıdan ele alması sebebiyle alana katkı sağlayacağı düşünülmektedir.

\section{Yöntem}

\section{Araştırmanın deseni}

Araştırmanın deseni nitel desenlerden eylem araştırmasıdır. Eylem araştırmaları bir alanda var olan bir problemin çözüm veya iyileştirilmesinde kullanılan bir araştırma desenidir. Ayrıca eylem araştırmasında belirli bir sürecin belirli bir ortamda uzun bir süre çalışılması ve var olan sorunla ilgili veri toplama sürecini de içerisinde barındırır (Yıldırım ve Şimşek, 2013). Eylem araştırmasının kullanıldığı bu araştırmada veriler içerik analizi ile elde edilmiş̧tir.

\section{Veri toplama araçları}

Veri toplama aracı araştırmacılar tarafından geliştirilmiştir. Veriler dört sorudan oluşan görüşme tekniği ile elde edilmiştir. Görüşmede yer alan sorular sondalar ile desteklenmiştir. Hazırlanan görüşme sorularının güvenirliğini sağlayabilmek için alanda uzman üç araştırmacıdan görüş alınmıştır. Araştırmacıların görüşleri doğrultusunda sorular düzenlenmiş ve çalışma grubundan veriler toplanmıştır. 


\section{Verilerin analizi}

Araştırmacılar tarafından görüşme formunda yer alan sorular katılımcılara yöneltilmiş, verilen cevaplar hem ses kayıt cihazıyla hem de not etmek suretiyle kaydedilmiştir. Ses kayıt cihazıyla kaydedilen veriler yazıya dökülerek deşifre edilmiş, alınan notlarla karşılaştırılmış, sonraki süreçte katılımcılara sunularak onların onayları alındıktan sonra verilerin analizine geçilmiştir.

\section{Geçerlik ve güvenirlik}

Araştırmanın iç geçerliliğinin arttırılması için alan yazın taraması yapılmış, özellikle bu çalışmanın gerekliliği araştırmanın giriş kısmında açıklanmıştır. Araştırmanın dış geçerliliğini arttırmak içinse araştırmanın yöntem başlı̆̆ altında araştırma süreci ve bu süreçte yapılanlar, veri kaynağı, verilerin çözümlenip yorumlanma aşamaları ayrıntılı bir biçimde açılanmıştır.

Araştırmanın güvenirliğini sağlamak amacıyla iki araştırmacı tarafından bulgular ayrı ayrı kodlanmış, Miles ve Huberman (1994) tarafından önerilen formülle karşılaştırılmış ve aralarındaki uyuşma durumuna bakılmıştır. Yapılan karşılaştırma sonucunda iki araştırmacı arasındaki uyuşma oranı \%96 olarak belirlenmiş, buradan hareketle araştırma bulgularının güvenilir olduğuna kanaat getirilmiştir.

\section{Araștırmanın amacı}

Araştırmanın amacı, yabancı dil olarak Türkçe öğretiminde kullanılan ders kitapları hakkında öğrencilerin görüş, fikir ve önerilerini almaktır.

Araştırma süresince şu dört soruya cevap aranmıştır;

1. Kullandı ̆̆ınız ders kitabını içerik yönünden yeterli buluyor musunuz? Neden?

2. Kullandığınız ders kitaplarının fiziksel yönden yeterli buluyor musunuz? Neden?

3. Kullandığınız ders kitabının ve çalışma kitaplarının yazarı siz olsaydınız hangi değişiklikleri yapardınız?

4. Set içerisindeki yardımcı materyaller (ses cd) yeterli mi? Niçin?

\section{Araștırmanın önemi}

Yabancı dil olarak Türkçe öğretim materyalleri hakkında daha önce yapılan araştırmalarda çoğunlukla alandaki uzmanlardan görüş alınıp çalışmalar bu doğrultuda değerlendirilmiştir. Yabancı dil olarak Türkçe öğretiminde kullanılan materyaller hakkında öğrenci fikir ve görüşlerini ön plana çıkaracak çalışma sayısı yok denecek kadar azdır. Bu sebeple araştırmanın alana katkı sağlayacağı düşünülmektedir.

\section{Çalışma grubu}

Araştırmanın çalışma grubunu Türkiye'nin güneyinde bir Türkçe öğretim merkezinde eğitimini tamamlamış (A1, A2, B1, B2 ve C1 hepsi) $10 \mathrm{klz} 10$ erkek olmak üzere 20 öğrenci oluşturmaktadır. Çalışma grubunda yer alan öğrenciler öğrenim süreçleri boyunca A1 seviyesinden C1 seviyesine kadar 
“İstanbul Türkçe Öğrenim Seti” ni kullanmışlardır. Çalışma grubundaki öğrenciler “Ö” şeklinde kodlanmış ve numaralar verilmiştir. Çalışma grubunun demografik özellikleri aşağıda verilmiştir.

Tablo 1. Çalışma Grubunun Demografik Özellikleri

\begin{tabular}{lll} 
Öğrenciler & Eğitim Durumu & Uyruk \\
\hline Ö1 & Lisans & Uganda \\
Ö2 & Lisans & Filistin \\
Ö3 & Lisans & Türkmenistan \\
Ö4 & Yüksek Lisans & Irak \\
Ö5 & Lisans & Afganistan \\
Ö6 & Lisans & Çad \\
Ö7 & Lisans & Iran \\
Ö8 & Lisans & Komorlar \\
Ö9 & Lisans & Komorlar \\
Ö10 & Lisans & Moğolistan \\
Ö11 & Lisans & Karadağ \\
Ö12 & Yüksek Lisans & Tunus \\
Ö13 & Lisans & Tunus \\
Ö14 & Lisans & Türkmenistan \\
Ö15 & Lisans & Irak \\
Ö16 & Yüksek Lisans & Tunus \\
Ö17 & Lisans & Irak \\
Ö18 & Lisans & Arnavutluk \\
Ö19 & Lisans & Madagaskar \\
Ö20 & Yüksek Lisans & Mali \\
\hline
\end{tabular}

\section{Araştırma süreci}

Öğrencilere alan uzmanlarına danışlarak hazırlanan sorular sorulmuş ve bunlara verdikleri cevaplar ses kayıt cihazıyla kaydedilmiştir. Ses kayıtları alınırken araştırmacı tarafından aynı zamanda verilen cevaplar yazılarak kodlanmıştır. Daha sonra kaydedilen ses kayıtları yazıya aktarılmıştır. Ses kayıtları ile araştırmacının tuttuğu notlar karşılaştırılarak verilerin sağlaması yapılmıştır. Sonra her soru ayrı şekilde değerlendirilmiş ve öğrencilerin verdiği genel cevaplar doğrultusunda başlıklar oluşturulmuştur. Bu başlıklara göre de veriler analiz edilmiştir. 


\section{Bulgular}

Araştırmanın bu bölümünde araştırmanın verileri örneklendirilerek yorumlanmıştır.

Tablo 2. Kullanılan Öğrenim Setinin İçeriği ile İlgili Öğrenci Görüşleri

\begin{tabular}{lll}
\hline Konular & f & $\%$ \\
Örnekler yeterli & 4 & 20 \\
Örnekler yeterli değil & 6 & 30 \\
Dil bilgisi yeterli & 5 & 25 \\
Dil bilgisi yeterli değil & 11 & 55 \\
Beceri etkinlikleri yeterli & 5 & 25 \\
Beceri etkinlikleri yeterli değil & 4 & 20 \\
\hline
\end{tabular}

Tablo 2'ye bakıldığında öğrenim setinin içeriği ile ilgili öğrencilerin örnekler, dil bilgisi ve beceri etkinlikleri olmak üzere üç ana konu üzerinde fikir belirttikleri görülmektedir. Öğrenim setindeki örneklerle ilgili 10 öğrenci görüş belirtmiştir. Bunların 6'sı örneklerin yeterli olmadığını, 4’ü yeterli olduğunu dile getirmiştir. Dil bilgisi konuları ile ilgili 16 öğrenci görüş belirtmiştir. Bu öğrencilerden 5’i öğrenim setindeki dil bilgisi konularının yeterli olduğunu, 11’i ise yeterli olmadığını belirtmiştir. Öğrenim setindeki dil bilgisi konuları ile ilgili 4 öğrenci de görüş belirtmemiştir. Öğrenim setinde yer alan beceri etkinlikleri (Okuma, yazma, dinleme ve konuşma) ile ilgili 9 öğrenci görüş belirtmiştir. Bu öğrencilerden 4’ü beceri etkinliklerinin yeterli olmadığını 5 ’i ise yeterli olduğunu belirtmiştir. Bu konuda da 11 öğrenci hiçbir görüş belirtmemiştir. Bu bulgular ile ilgili örnekler şu şekildedir:

\section{Örnekler yeterli}

Ö9: "Bol bol örnekler ve ödev veriliyor.”

Ö7: “Çok fazla örnekler veriyor fazla bir şeyler geliyor.”

\section{Örnekler yeterli değil}

Ö8: “Örnekleri çok az verildi.”

Ö6: "Mesela bir dil bilgisi okuyorsun sonra dört beş örnekler var. Bu örnekler az."

\section{Dil bilgisi yeterli}

Ö9: "Dil bilgisinde kurallar nerede ve nasıl kullanılıyor anlatıyor.”

Ö6: "Bence dil bilgisi çok güzel ve yani çok şeyler öğrendik a1 den buraya kadar ve bütün gramerler öğrendik.”

\section{Dil bilgisi yeterli değil}

Ö4: "Mesela bir gramer bu şekilde konulmuş başka şekli de var hocalar bize öğrettiler." 
Ö18: "Bazen gramer çok yetersizdi. Mesela ben okuyodum anlamıyodum. Bazen hocalar daha fazla veriyodu bu yüzden anlıyodum. Mesela fazla notlar veriyodu tahtada alıyodum öyle anlıyodum.”

\section{Beceri etkinlikleri yeterli}

Ö5: "Bence mükemmel bir kitap. Sıkıntı böyle bir şey var. Okuma var, dinleme var dil bilgisi var. Yani bence her konu hakkında ayrı ayrı kitaplar yazacaksa daha iyi olur."

Ö15: "ama okuma çok iyiydi bence okuma metinleri çok iyiydi yani a1 den c1 e kadar ben fark ettim okuma pay pay zorlaşıyor.”

\section{Beceri etkinlikleri yeterli değgil}

Ö8: "Kitabın düzenlenme şekli biraz karışık. Okuma parçası çok azdır. Bazı konuşma ve yazmalarda bazıları çok saçma buluyorum. Son olarak yazma hakkında biraz açıklamak olmalı."

Ö2: "Konuşma yeterli değil. Bu yüzden iyi konuşmuyoruz."

Tablo 3. Kullanılan Öğrenim Setinin Fiziksel Özellikleri ile İlgili Öğrenci Görüşleri

\begin{tabular}{lll}
\hline Konular & f & $\%$ \\
Görseller yeterli & 4 & 20 \\
Görseller yeterli değil. & 7 & 35 \\
Boyut uygun & 4 & 20 \\
Boyut uygun değil & 4 & 20 \\
Kâ̆̆ıt kalitesi yeterli. & 4 & 20 \\
Kâğıt kalitesi yeterli değil & 3 & 15 \\
Diğer görüşler(sağlamlık/yazım kalitesi) & 8 & 40 \\
\hline
\end{tabular}

Tablo 3'e bakıldığında öğrenim seti ile ilgili fiziksel bulgular incelendiğinde öğrenciler üç ana konu üzerinde görüş belirtmiştir. Bu konular: kitaplarda yer alan görseller, kitapların boyutları ve kitaplarda kullanılan kâğıdın kalitesi ile ilgilidir. Görsellerle ilgili 11 öğrenci görüş belirtmiştir. Bu öğrencilerden 4’ü öğrenim setindeki görsellerin yeterli olduğunu 7'si ise yeterli olmadığını dile getirmiştir. Görsellerle ilgili 9 öğrenci görüş belirtmemiştir. Boyutla ilgili görüş dile getiren öğrenci sayısı 8'dir. Bu öğrencilerden 4'ü öğrenim setinde yer alan kitapların boyutlarının yeterli, 4'ü de yetersiz olduğunu belirtmiştir. Öğrenim setinin boyutuyla ilgili 12 öğrenci görüş belirtmemiştir. Kâğıt kalitesi ile ilgili görüss bildiren öğrencilere gelindiğinde 7 öğrenci görüş bildirmiştir. Bu öğrencilerin 4’ü öğrenim setinde yer alan kitapların kâğıt kalitesinin yeterli olduğunu 3’ü ise yetersiz olduğunu dile getirmiştir. Bu konuda 13 öğrenci görüş belirtmemiştir. Yukarıda sayılan üç konu dışında farklı konularda görüş belirten öğrenci sayısı ise 8'dir. Bu bulgular ile ilgili örnekler şu şekildedir:

\section{Görseller yeterli}

Ö11: "Evet yeterli kaliteli. Çok resimler fotoğraflar var anlatıyorlar.”

Ö20: "Evet yeterli bol bol fotoğraflar var. Bu yüzden her şey kolay anlıyorum...”

\section{Görseller yeterli değil}


Ö1: "Görsel bence biraz geliştirmesi lazım. Daha görsel lazım özellikle ilk seviye kitaplar mesela a1 veya a2 daha fazla görsel lazım."

Ö2: "Bütün resimler İstanbul hakkında ama başka şehirler olmalı."

\section{Boyut uygun}

Ö1: “Ama büyüklük kitap büyüklük ağır değil çok uygun. Çanta koymak için çok uygun taşımak çok uygun"

Ö11: "Taşımak için çok kolay oluyor.”

\section{Boyut uygun değil.}

Ö14: "C1 kitabı çok ağır.”

Ö17: "Sadece C1 kitabında çok büyük çok ağır.”

\section{Kâğnt kalitesi yeterli}

Ö17: “...resimler belli ve sayfalar çok kaliteli iyi...”

Ö6: "Kitap kâğıt kaliteli”

\section{Kâ̆ğıt kalitesi yeterli değil}

Ö11: "Bazen yazıyoruz renk başka kağıda gidiyor.”

Ö2: “Kitapta yazarken yazdıklarımız iyi görünmüyor.”

\section{Diğer görüşler (Să̆lamlk/Yazm Kalitesi)}

Ö7: “ïlk A1 kitapları çabuk açıldı. A1 dağıldı.”

Ö3: "Mesela Eğer tükenmez kalemle yazıyoruz sorun oluyor."

Ö4: "Üzerine yazabilmek için her kalemle yazmazsın.”

Tablo 4. Öğrencilerin Kullanılan Öğrenim Setindeki Kitaplar Üzerinde Yapmak İstedikleri Değişiklikler ile İlgili Görüşler

\begin{tabular}{lll}
\hline Konular & f & \% \\
Dil bilgisi ile ilgili görüşler & 10 & 50 \\
Beceri etkinlikleri ile ilgili görüusler & 8 & 40 \\
Kitapların fiziksel özellikleri ile ilgili görüşler & 5 & 25 \\
\hline
\end{tabular}

Tablo 4'e bakıldığında öğrencilerin öğrenim setindeki kitaplarda yapmak istedikleri değişikliklerle ilgili bulgularda üç konu göze çarpmaktadır. Bu konular: beceri etkinlikleri, dil bilgisi ve kitapların fiziksel özellikleri ile ilgilidir. Dil bilgisi ile ilgili 10 öğrenci görüş belirtmiş, 10 öğrenci görüş 
belirtmemiştir. Beceri etkinlikleri ile ilgili 8 öğrenci görüş belirtirken 12 öğrenci görüş belirtmemiştir. Kitapların fiziksel özellikleri ilgili 5 öğrenci görüş belirtmiş, 15 öğrenci bu konuda fikir belirtmemiştir. Bu görüşler şu şekilde örneklendirilmiştir:

\section{Dil bilgisi ile ilgili görüşler}

Ö7: “Mesela gramerleri birkaç sayfa kitap sonunda yazsa bu çok güzel olur.”

Ö12: "Dediğim gibi dil bilgisi daha fazla açıklama yapardım yani."

\section{Beceri etkinlikleri ile ilgili görüşsler}

Ö1: “Başka şey var. Konuşma hakkında farklı konular ve biraz detay yazacaktım.”

Ö5: "Her konuda ayrı ayrı(kitap) yazardım.”

\section{Kitaplarm fiziksel özellikleri ile ilgili görüşler}

Ö6: "Çalışma kitabı renksiz güzel değil. Rengi değiştireceğim.”

Ö3: "Alıştırma kitabı renksiz. Onu renkli yaparsam daha güzel olur.”

Ö18: "Çalışma kitabında var cevaplar onları koymayacaktım. Herkes okuyor zaten hiç kimse kendisi yapmiyor oradan okuyor."

Tablo 5. Öğrencilerin Öğrenim Setinde Bulunan Yardımcı Materyaller (Ses CD’si) ile İlgili Görüşleri

\begin{tabular}{lll}
\hline Konular & f & \% \\
Yardımcı Materyaller yeterli & 3 & 15 \\
Yardımcı Materyaller yeterli değil & 12 & 60 \\
Diğer (Video olmalı) & 12 & 60 \\
\hline
\end{tabular}

Tablo 5'e bakıldığında öğrenim setinde yer alan yardımcı materyaller ile ilgili öğrenciler üç ana konu üzerinde görüş belirtmişlerdir. Görüş bildiren öğrencilerden 3’ü yardımcı materyallerin yeterli olduğunu, 12'si yeterli olmadığını belirtmiştir. Farklı konular ile ilgili görüş bildiren öğrenci sayısı da 12'dir. Bu görüşler şu şekilde örneklendirilebilir:

\section{Yardımen Materyaller yeterli}

Ö10: “Evet yeter çünkü bi konuda bir ya da iki dinleme varsa yeter.

Ö3: "Ses cdleri bence yeterli sesler de güzel yani tam sokakta konuşulan Türkçe gibi güzel yani."

Ö1: "Sesler kaliteli iyi. Bazen de değil bence bunu bizim daha iyi öğrenmek için böyle yapıyor. Kalite değil ama bunu yapınca benim dinleme beceri biraz gelişiyor. 


\section{Yardımcı Materyaller yeterli değil}

Ö6: "Özellikle erkekler yani sesleri çok kötü mesela dinlerken hiç anlamıyorsun yani. Ve bayanlar yani çok hızlı konuşuyorlar.”

Ö5: "Bence ses kalitesi o kadar iyi değil çok hızlı konuşuyor. Bazen hocamla konuşuyordum bu konuşmalar Rap gibi öyle çok hızlı."

\section{Diğer (Video)}

Ö11: "Cd yerine belki video isterdim.”

Ö10: "Video olsa daha yardımcı olur."

Ö5: “Mesela videolar, Münazaralar, tartışmalar öyle şeyler yoktu. Şimdi o kadar iyi olmuyor.”

\section{Sonuç ve öneriler}

Araştırmanın bulgularından hareketle şu sonuçlara varılabilir:

Öğrenim setinin içeriği ile ilgili 6 öğrenci örneklerin yeterli olduğunu, 3 öğrenci ise yetersiz olduğunu belirtmiştir. Görüş belirten 9 öğrenciden 6'sının olumlu yönde görüş belirtmesi öğrenim setindeki örneklerin yeterli olduğu anlamına gelebilir. Bununla beraber, 11 öğrenci dil bilgisi konularının anlatımlarının yetersiz olduğunu, 5 öğrenci ise bu konuların anlatımlarının yeterli olduğunu belirtmiştir. Dil bilgisi konuları ile ilgili görüş belirten 16 öğrenciden 11'inin olumsuz görüş belirtmesi öğrenim setindeki dil bilgisi konularının gözden geçirilmesi gerektiğini ortaya koymuş olabilir. Ayrıca beceri etkinlikleri ile ilgili 4 öğrenci beceri etkinliklerinin yetersiz olduğunu daha fazla etkinlik konması gerektiğini belirtirken 5 öğrenci ise bu etkinliklerin yeterli olduğunu belirtmiştir. Buradan hareketle beceri etkinliklerinin de geliştirilmesi gerektiği düşünebilir.

Öğrenim setinin fiziksel özellikleri ile ilgili 11 öğrencinin 7'si görseller ile ilgili olumsuz görüş belirtirken 4 öğrenci olumlu görüş belirtmiştir. Görüş belirten 11 öğrenciden 7'sinin olumsuz görüş belirtmesi öğrenim setinde yer alan görseller üzerinde öğrenci görüşlerine paralel bir şekilde değişiklikler, düzenlemeler ve geliştirmeler yapılması gerektiğini düşündürebilir. Kılıç ve Yenen (2015)'in yaptığı "Yabancılara Türkçe Öğretiminde Kullanılan Ders Kitaplarına İlişkin Öğretim Elemanlarının Görüşleri” adlı çalışmada öğretim elemanlarının büyük çoğunluğu kitaplardaki görsellerin artırılması gerektiğini ortaya koymuşlardır. Bu açıdan bakıldığında bu çalışmanın sonucuyla tarafımızca yapılan araştırmanın sonucunun birbirleriyle örtüştüğü düşünülebilir. Yine setle ilgili 8 öğrenciden 4’ü kitapların boyutu hakkında olumsuz görüş belirtirken 4 öğrenci olumlu görüş belirtmiştir. Buradan hareketle kitapların boyutuyla ilgili de düzenlemeler yapılması gerekebilir. Kâğıt kalitesi ile ilgili 7 öğrenciden 3’ü olumsuz görüş belirtirken 4 öğrenci olumlu görüş belirtmiştir. Bu görüşlerden farklı olarak 4 öğrenci kitapların çabuk yırtıldı̆̆ını, 4 öğrenci ise uygulama boyutunda bu kitapların üzerine her kalemle yazı yazılamadığını belirtmiştir. Bu sonuçla öğrenim setinde yer alan kitapların sayfa kalitesinin iyi olduğu ancak dayanıklılık konusunda yeterli olmadığı düşünülebilir. Ayrıca sayfaların kâğıt yapılarında değiş̧iklik yapılıp yazım açısından daha kullanışlı hâle getirilmesi düşünülebilir. 
Öğrencilerin kullanılan öğrenim setindeki kitaplar üzerinde yapmak istedikleri değişiklikler ile ilgili 10 öğrenci dil bilgisi konuları ile ilgili değişiklikler yapacă̆ını, 8 öğrenci öğrenim setinde yer alan dil becerileri ile ilgili değişiklikler yapacağını, 5 öğrenci de fiziksel olarak değişiklikler yapacağını belirtmiştir. Bu konuda görüş belirten öğrencilere bakıldığında öğrenim setinde yer alan dil bilgisi konularının gözden geçirilerek düzenlemeler yapılması gerektiği düşünülebilir. Buna ek olarak öğrenim setinde yer alan dil becerileri ile ilgili etkinlikler üzerinde de düzenlemeler yapılması gerekliliği düşünülebilir.

Öğrenim setinde bulunan yardımcı materyaller (ses materyalleri) ile ilgili görüşlere gelindiğinde 3 öğrenci yardımcı materyallerin yeterli olduğunu belirtirken 12 öğrenci bu materyallerin yetersiz olduğu görüşünü belirtmişlerdir. Ayrıca diğer bulgular başlığı altında da 12 öğrenci öğrenim setine yardımcı materyal olarak sesli ve görüntülü materyallerin eklenmesi gerektiğini belirtmişlerdir. Araştırmaya katılan 12 öğrencinin öğrenim setindeki yardımcı materyal (Ses CD’si) ile ilgili olumsuz görüş belirtmesi bu materyallerin değiştirilerek yeniden ele alınması gerekliliğini akla getirebilir. Kılıç ve Yenen (2015) de yaptıkları çalışmada ses cd'lerinin interaktif bir hale getirilmesi gerektiği sonucuna ulaşmışlardır. Elde ettikleri bu sonucun yapılan bu çalışma ile aynı doğrultuda olduğu savunulabilir. Yine öğrencilerden 12'sinin yardımcı materyalleri sesli ve görüntülü olarak beraber ele alınması fikri değerlendirilerek bu türde materyallerin öğrenim setine eklenmesi gerekliliği göz önünde bulundurulabilir. Bu durum Gün, Akkaya ve Kara (2014) 'nın yaptı̆̆ "Yabancılara Türkçe öğretimi ders kitaplarının Türkçe öğretim merkezlerinde görev yapan öğretim elemanları açısından değerlendirilmesi” adlı çalışmadaki ses kayıtlarının videolarla desteklenmesi gerektiği sonucu ile örtüşmektedir.

Araştırma sonuçları ile ilgili şu öneriler getirilebilir:

Daha kesin sonuçlara ulaşmak açısından aynı araştırma daha geniş bir çalışma grubu ile yapılabilir.

Aynı öğretim setinin kullanıldığı başka dil öğretim merkezlerinde aynı çalışma yapılarak sonuçlar bir de bu açıdan değerlendirilebilir.

\section{Kaynakça}

Arslan, A. ve Coşkun A. (2012). Avrupa Dilleri Ortak Çerçeve Programı: Türkiye ve Dünyada Neler Oluyor?, Abant İzzet Baysal Üniversitesi Sosyal Bilimler Enstitüsü Dergisi, 12, 1-19.

Bayraktar, S. (2015). Yeni Hitit 1 Yabancılar İçin Türkçe Ders Kitabının Kültür Aktarımı Açısından İncelenmesi, Hacettepe Üniversitesi Yabancı Dil Olarak Türkçe Araştırmaları Dergisi, 2, s. 723.

Coşkun, O. (2017). Ders araç ve gereçleri, materyal tasarımı, dil eğitiminde bilişim teknolojileri ve sosyal medya kullanımı. H. Develi vd. (Ed.). Uygulamalı Türkçenin yabancı dil olarak öğretimi el kitabı içinde (s.237-324). Ankara: Kesit Yayınları.

Göçer, A. (2007). Türkçenin yabancı dil olarak öğretiminde kullanılan ders kitaplarının ölçme ve değerlendirme açısından incelenmesi. Dil Dergisi, 137, s.30-48.

Gün, M., Akkaya, A. ve Kara, Ö. T. (2014). Yabancılara Türkçe öğretimi ders kitaplarının Türkçe öğretim merkezlerinde görev yapan öğretim elemanları açısından değerlendirilmesi. Turkish Studies, (9)6, p. 1-16.

Güzel, A. ve Barın E. (2013). Yabancı dil olarak Türkçe öğretimi. Ankara: Akçağ Basın Yayın.

Hirschfelder, A.,Molin, P. F. \&Wakim, Y. (1999). American Indian stereotypes in the World of Children: A Reader and Bibliography (2nd Edition). Maryland, NJ: The Scarecrow. 
İşcan, A. ve Yassıtaş, T. (2018). Yabancı dil olarak Türkçe öğretimi ders kitaplarında kültür aktarımı: yedi iklim Türkçe öğretim seti örneği (b1-b2 düzeyi), Aydın Tömer Dil Dergisi, (3)1, s. 47-66.

Karababa, Z. C. ve Üstünsoy Taşkın, S. (2012). Yabancı dil olarak Türkçe öğretiminde kullanılan ders kitaplarının öğretmen görüşleri çerçevesinde değerlendirilmesi, Dil Dergisi, 157, s. 65-80 .

Kılınç, H. H. ve Yenen, E. T. (2015). Yabancılara Türkçe öğretiminde kullanılan ders kitaplarına ilişkin öğretim elemanlarının görüşleri. International Journal of Language Academy, 3/4, s. 429-441.

Miles, M.B. \& Hubermann, M.A. (1994) Qualitative analysis: An expand source book. 2nd. Ed. Thousand Oaks, CA: Sage.

Sarıçoban, A. (2015). Yabancı dil olarak Türkçe öğretimine genel bir bakış. A. Sarıçoban (Ed.), Yabancı dil olarak Türkçe öğretimi Metodolojisi içinde (s.2-11). Ankara: Anı yayıncılık.

Yıldırım, A. ve Şimşek, H. (2013). Sosyal Bilimlerde Nitel araştırma Yöntemleri (9.Baskı). Ankara: Seçkin Yayıncılık.

Yeşilyurt, E. (2019). Yabancı dil olarak Türkçe öğretimi için hazırlanmış ders kitapları. Ü. Şen (Ed.). Yabancı dil olarak Türkçe öğretimi, içinde (s.167-19o). Ankara: Pegem Akademi 